\title{
The Theological and Social Context of Inclusive Support for People with Disabilities Provided by the Christian Community Alena Vyskočilová, Josef Slowík
}

\begin{abstract}
The study presents the theoretical context of an inclusive approach to people with disabilities and disadvantages, not only as a modern social phenomenon, but also from the point of view of Christian theology and practical Christianity within the ecclesial community. The qualitative research used a phenomenographic interview with a woman with physical disability and also her two friends from the Christian community; it presents the possibilities and the pitfalls of inclusive support in such a community for persons with disabilities. Respondents' testimonies point to some categories of needs of persons with disabilities, in which the naturally pro-inclusive Christian community can play an important (or indispensable) role, and even in terms of social work this resource of support has significant potential.
\end{abstract}

Key words: social inclusion, inclusive support, person with disability, Christian community

\section{Introduction}

Although the media image of the word 'inclusion' is perceived by the public rather in connection with education in recent years, it is in fact a much wider phenomenon, covering practically all areas of human social existence. The principle of an inclusive approach is (in a simplified manner) respect for difference and the right of each individual to equal membership in the community and society. ${ }^{1}$ Therefore, the concept of inclusion is most often mentioned in relation to those who are most at risk of being deprived of this respect (by the majority population and sometimes even by their immediate neighbourhood), that is, people at risk of a certain level of social exclusion mostly the disabled or socially (or socio-culturally) disadvantaged.

As we will try to show later in this paper, from the point of view of social work, which (according to some important authors) primarily stems from the tradition of Christian humanism and whose more detailed definition we will offer in Chapter 2, the element of the inclusive approach is unambiguously the fundamental value in the system of this field. At the same time, in theory, we can understand from the - at least brief - definition of the current discourse of social inclusion

1 Cf. Thomas P. LOMBARDI, Inclusion: policy and practice, Bloomington: Phi Delta Kappa Educational Foundation, 1999 , p. 10. 
(in Chapter 1) whether, why, and how Christianity and the Christian community (respectively, the Church) could and should themselves reflect this approach and become pro-inclusive (respectively, to actively prefer this direction and values). The aim of our study, however, is to further map the real potential and define the specific possibilities of the Christian (Church) community in promoting an inclusive and quality life of a person with disabilities, using a qualitative study of the story of a particular person, with subsequent interpretations of some more generally applicable outcomes.

\section{Social Inclusion and Support for People with Disabilities and Disadvantages}

One possible definition explains inclusion very simply as the opposite of exclusion, that is, social exclusion, which occurs when an individual does not take part in key activities for a period of time for reasons beyond his or her control. ${ }^{2}$ According to Boardman, true social inclusion is based on personal choices in such matters as who I am in contact with, how I can spend my time, etc. (or even free access to relevant information). This choice is very often dependent on the decision and interest of both parties, not just the individual. ${ }^{3}$

O'Halloran sees social inclusion as a modern sociological concept with ancient roots, which has been updated as a contemporary approach since the 1970s. It is not only policy, but a process based on a combination of different social strategies. Social inclusion, however, is directed against the reality of social exclusion that occurs when an individual is not involved in certain (key) activities in his or her society for reasons that he or she cannot influence even though he or she himself would like to participate. ${ }^{4}$

The Sociological Dictionary defines social inclusion as also 'a higher degree of integration of disabled or disadvantaged individuals into society and its institutions'; the assumption of successful inclusion is the acceptance by other members of the group. ${ }^{5}$ The frequently confused terms of integration and inclusion, however, are essentially distinguished by Prucha. His distribution is based on the degree of mutual adaptation of the individual and the environment: while in the case of integration, a higher degree of adaptation is expected from a person with a disadvantage, inclusion mainly involves the removal of environmental barriers. An inclusive approach, therefore, does not mean only the formal integration of the individual into society, but presupposes a radical change of values and attitudes on the side of society in the sense of emphasising the potential of each (the disabled or disadvantaged included) member, whose participation needs to be assured by a common looking for possibilities and opportunities. ${ }^{6}$

The principle of inclusion and its human rights concept combine the ideas of respect for the difference and the right of an individual to equal membership in society. ${ }^{7}$ This is not a phenomenon that would reveal needs and shortcomings only in the context of less developed democracies, which is evident from historical experience (for example, the attitude towards children with disabilities in the field of education, comparing the Czech Republic and USA, was very similar in the middle of the 20th century - and even today in such a developed country, parents of children with disabilities encounter sometimes the same problems as here in the Czech Republic in the

Cf. Josef SLOWÍK, Dobrovolnictví jako nepostradatelný nástroj sociální inkluze, Sociání práce / Sociálna práca, 4/2011, pp. 43-48.

Cf. Jed BOARDMAN, Social inclusion and mental health, London: Royal College of Psychiatrists, 2010 , pp. 45-46.

Cf. Kerry O'HALLORAN, Charity law and social inclusion: an international study, New York: Routledge, 2006, p. 40.

Jan JANDOUREK, Sociologický slovník, Praha: Portál, 2001, p. 107.

Jan PRŮCHA, Eliška WALTEROVÁ and Jiří MAREŠ, Pedagogický slovník, Praha: Portál, 2009 , pp. 104 and 107.

Cf. LOMBARDI, Inclusion: policy and practice..., p. 10. 
real enforcement of their children's fundamental right). ${ }^{8}$ Some authors place the current debate on the inclusion of disadvantaged people at the same level as the general problem of our current developed society, which boasts of references to democracy guaranteeing equal rights for all but internally it is becoming increasingly informally (and often with some significant formal manifestations) structured into social classes where some individuals or groups find themselves in the position of being less significant or valuable and sometimes even 'lower' members - which we can, according to Allan, call 'character corrosion.' In fact, a similar phenomenon - a regression rather than a progression of the positive development of the society relationship to its disadvantaged members - is also recognised by Titzl, who in his reflection of the historical approach to people with disabilities in antiquity and the Middle Ages states that 'the world of the non-disabled and the world of disabled was (with some exceptions) one. In those days everyone was far more visible to the eyes of others; the separation of the two worlds, especially by the establishment of special institutes, was brought by modern times. ${ }^{10}$

Current inclusive trends are also related to changes in the paradigm in assisting professions, especially with the current orientation on the application of the Person-Centred Approach. Each person is unique and lives in a connected way with the surrounding environment. This interaction between a person and his or her environment is often defined by the term 'social functioning. ${ }^{11}$ The view of a life situation through the lens of the concept of social functioning allows us simultaneously to look at the creation of individual coping strategies as well as the requirements of the environment given by the social context. And just like social environments place certain requirements on people that one has to react to, in the same way an individual has certain expectations from society. Therefore, the interaction should ideally be in equilibrium. The life situation with a severely disturbed balance (when one is not able to meet the expectations of society) should be solved by social work as well. Support (including support provided by professional social workers) to a person in a difficult life situation should be focused on creating coping strategies - that is, it should always be such an action which sets a balance between the requirements of the environment and the ability to manage the situation by the individual. ${ }^{12}$

The life situation of an individual is defined as a set of assumptions and barriers in the area of social functioning, which is manifested in four basic dimensions: biological, psychological, social, and noogenic. ${ }^{13}$ A holistic approach enables us to see the situation of a person in a complex way and at the same time in the different layers of his or her being. In the biological field, for example, a person with disabilities is particularly concerned with the management of physical constraints, the use of compensatory aids, the necessity of housing adaptation, rehabilitation, pain response, drug use, etc. In the psychological field, it is the ability of the person concerned to cope with his or her own disadvantage also in terms of self-concept, self-acceptance, self-reflection, etc. The social layer then represents a complex network of relations from the closest ones (e.g., partners, family members) to friends, neighbours, acquaintances, carers, and even members of the Church, etc. The relations with institutions are also significant (social support and services, health care, etc.). The noogenic layer, in other words, the spiritual layer, is closely tied to values - with issues which transcend man, with the search for the meaning of human existence, its fulfilment and transcen-

\footnotetext{
Cf. Linda EVANS, Inclusion, New York: Routledge, 2007, p. 5.

Cf. Julie ALLAN (ed.), Inclusion, participation, and democracy: what is the purpose?, Dordrecht: Kluwer Academic, 2003, p. 19.

Boris TITZL, Postižený člověk ve společnosti, Praha: Univerzita Karlova, 2000, pp. 234-235.

Cf. Pavel NAVRÁTIL, Teorie a metody sociální práce, Brno: Marek Zeman, 2001, p. 12.

Cf. ibid, pp. 12-13.

Cf. Pavel NAVRÁTIL and Libor MUSIL, Sociální práce s př́slušníky menšinových skupin, Sociální studia 5/2000, p. 133.
} 
dence. ${ }^{14}$ Taking into account Maslow's hierarchy of needs, we find the need for self-actualisation at its fifth level. Maslow calls this level a B-level, and its upper limit for filling remains permanently open. A self-actualising person is directed to so-called B-knowledge, to the knowledge of being which is focused on existence in its deepest meaning. The very effort to meet the needs at this level leads to the creation of a set of values which Maslow calls B-values. These include individual integrity, dedication, inner richness, spontaneity, ease, playfulness, honesty, and self-sufficiency. ${ }^{15}$

\section{Theological Basis of the Christian Approach to People with Disabilities}

It is not difficult to find the fundamental intersections of the theory of social work and basic Christian principles if we understand social work as a science discipline based principally on the mutual equality of all people, the application of mutual respect, respect for human dignity, and respect for human rights - as stated in the justification of the Quality Standards of Social Services. ${ }^{16}$ In this connection, Doležel refers also to the declaration of the document Human Rights and Social Work, in which the service for the poor and the needy is declared as a reason for the realisation of social work. ${ }^{17}$ Matoušek states that the basic principle of social work is solidarity, which is enshrined in our culture primarily in the Christian concept of our neighbour. ${ }^{18}$ The same author also points to the 'theory of natural law', based, among other things, on the tradition of Christianity (but also on other world religions). He states that it is one of the fundamental ethical theories relevant to the professional ethics of social workers. As one of the possible value orientations important for the performance of a social worker he refers specifically to the religious value orientation. ${ }^{19}$ The clear and narrow theoretical and practical contexts of theology (and philosophy) with social work are also seen by Fischer and Jandejsek, who also emphasise the importance of including theological and philosophical foundations in the standard content of qualification training and education of social workers. ${ }^{20}$

The principle of solidarity and attitude towards people as our (equal) neighbours is found in the biblical message of the Old and New Testaments. The oldest legal norms listed in chapters 20 to 23 of Exodus put the care of the weak and the poor before the eyes of God at the same level as care for the right cultic-ritual behaviour. ${ }^{21}$ Virtually identical requirements are repeated in Deuteronomy, the collection of laws from the end of the period of the kings (7th century BC). Socially endangered groups include old people, widows and orphans, foreigners, poor, slaves, or labourers. Motivation to help the needy in the Bible comes out from the character of the Lord Himself, who loves man, liberates him or her, and poses a vision of a positive future before him or her. Applying God's principles is not a matter of the distant future, but a matter of the day-to-day conduct of God's people. Just as they themselves experienced the help and other manifestations of God's dealings with his people (for example, the rescue from Egyptian slavery), in the same way everyone can and should apply this approach and principles by helping the socially weak and threatened ones: this is how to create a society based on God's righteousness. The definitive constitution of

14 Cf. ibid., pp. 132-133.

15 Cf. Victor J. DRAPELA, Přehled teorií osobnosti, Praha: Portál, 2008, p. 141.

16 Cf. Martin BEDNÁ̌̌, Kvalita v sociálních službách, Olomouc: Univerzita Palackého, 2012, pp. 59-60.

17 Cf. Jakub DOLEŽEL, Biblické kořeny sociální práce, in Michael MARTÍNEK et al. (eds.), Praktická teologie pro sociální pracovníky, Praha: Jabok, 2008, p. 26.

18 Cf. Oldřich MATOUŠEK, Prolegomena k teorii sociální práce, Fórum sociální práce / Social work forum 1/2011, p. 15.

19 Cf. Oldřich MATOUŠEK, Metody a řízení sociální práce, Praha: Portál, 2003, pp. 26-33.

20 Cf. Ondřej FISCHER and Petr JANDEJSEK, Teologicko-filosofické vzdělávání jako cesta ke spojení teorie a praxe v sociální práci, Sociální práce / Sociálna práca 4/2010, pp. 126-129.

21 Cf. DOLEŽEL, Biblické kořeny..., p. 29. 
such a society is not in human power, but the application of the principles of God's justice is possible to apply in everyday life. ${ }^{22}$

The New Testament message follows these thoughts and demands in Jesus' central message of the Kingdom of God. In the Gospel of Matthew, the principles of God's government are illustrated precisely by changing the situation of disadvantaged people, when the blind see, the lame walk, lepers are cleansed, the dead stand (Mt 4,23-24). According to the words of Jesus, the kingdom of God is everywhere where God's will is promoted amongst men, and where people act according to God's principles. Those are (in practice) reflected in the ecclesiastical tradition of deeds of physical and spiritual mercy. One should follow Christ by helping the needy ${ }^{23}$ And it is not just a formal declaration of help: Christ even comes to and identifies with those who are needy and socially least important (Mt 25:40). His kingdom is open to them (Lk 14:21), and the Church as His body is to be varied, composed of many different parts connected in one living organism by the one Spirit (1 Cor 12:27). Everyone should be welcomed (Acts 10) - and after all, the Church cannot refuse anyone because no one can decide this except the true leader of this community, Christ (1 Cor 12:14-26). If we look into the gospels and see the followers of Jesus (and later into the group of members of the early Church), we see that among the most socially threatened or directly excluded, the gospel usually received the greatest response (Mt 15:30; 1 Cor 1:26). An echo of the Old Testament God's command, 'Do not oppress the widow or the fatherless, the foreigner or the poor', (Zech 7:10, Deut 16:11,14; Ex 22:21), is then (in the New Testament) the clearly formulated requirement to 'remember widows and orphans in their pain', which even represents a measure of the 'true spirituality that is pure in the eyes of our Father God' (Jas 1:27).

Opatrný places the Attentive Heart of a Human (of a Christian) into a relationship with the professional competence of a modern social worker. He refers to the essence of the first element of charity which is (when talking about Christians) connected inseparably with the imperative of the essential requirement of 'doing what is most needed'. The term 'charity work' is therefore perceived today as 'the interaction between social work representing a secular field equipped with the autonomy of the earthly reality and the diaconal task of the Church, which also applies to specific individuals forming the Church' (so-called Christian charity work is, according to Opatrný, specifically and exclusively connected to the ecclesial context). ${ }^{24}$ In the example of the parable of the Good Samaritan, this author also shows the place of charity work when talking about the care of those who have fallen out of the social system and there is no one else who would return them back to the system (that is, 'passed by on the other side'); the boundaries of charity are now defined, for example, by leading and placing the specific person in need into system-provided social services. ${ }^{25}$ Both positions, however, meet and intersect in the personalities of Christians working in social services - and not just Christians, because other workers in helping professions often come across situations which require a response that is similar to the one we see when talking about the characters portrayed in the parable. ${ }^{26}$

One cannot ignore the long historical development of Christian teachings and Church practices,

\footnotetext{
Cf. ibid., p. 33.

Cf. ibid., p. 36.

4 Michal OPATRNÝ, Podobenství o milosrdném Samaritánovi a proprium křestanské charitativní práce v kontextu tzv. teorie charity, Studia Theologica 3/2016, pp. 167-169.

25 Even though Pope Benedict XVI underlines in his encyclical letter a specific philosophy of charity work, he also leaves no doubt about stating the basic and primary prerequisite for working on a charity work, namely, the professional competence. This one has to be put first. Cf. Jakub DOLEŽEL, Heinrich POMPEY, Impulzy pro sociální práci církve - encyklika Deus caritas est, Studia Theologica 3/2006, p. 55 .

26 Cf. OPATRNÝ, Podobenství o milosrdném Samaritánovi..., p. 179.
} 
with their roots ultimately growing into the present form of social work as a science as well as a practical discipline. Since the time of the Apostolic communes, for instance, the office of the diaconate has been established, and women (deaconesses) were involved since the beginning. From this period, there are also reports of material collections which gain importance in terms of communion (Greek koinonia) and service (Greek diakonia) by the apostle Paul. And if we move through history to the present, we can certainly mention, for example, a set of essential ecclesiastical documents defined by the tradition of the so-called social learning of the Church analysed (in connection with the development of current European policy and also its interpretation and the application of the principles of solidarity and subsidiarity), for example, by Míčka. ${ }^{27}$ Doležel further points to the modern paradigm of the integral development of a human being, including the cultivation of the client's spiritual dispositions and not only a 'holistic' approach to his or her needs; according to some authors, this corresponds to the discourse of so-called spiritually-oriented social work. ${ }^{28}$ All of this is essential for a better understanding of the context of mutual practical assistance, relationships in the Christian community, and their transcendence into the field of social work - and this is also the starting point for defining the possibilities of the Christian community when promoting the inclusive life of disabled people in society.

\section{Inclusive Potential of the Christian Community}

Exploring the possibilities and potential of the Christian community in promoting inclusive and quality life for people with disabilities is best done and presented in a real story - a real case study. We have therefore chosen a concrete example of the analysis - the life experience of a woman with physical disabilities attending the Christian community. This case is supplemented by an analysis of testimonies of two community members who are the woman's close friends and helpers (we can therefore describe them as 'helping people'). ${ }^{29}$

The method used in this qualitative research was a phenomenographic interview that allows the capture of the description and analysis of the processes by which one gains his or her experience, creates concepts, and tries to understand the events in his or her life and around him or her. The intention is, among other things, to distinguish qualitatively different ways of perception, conceptualisation, or understanding of the world..$^{30}$ Phenomenographic insight into the life of a person with a disability may be an opportunity to name and then remove barriers, prejudices, and stereotypes in society's approach to such an individual. ${ }^{31}$ The phenomenographic interview is a time-consuming process focused on the content depth of the testimony. The interview is not pre-structured and focuses on how the respondent gains the experience. ${ }^{32}$ Criticism of this methodical procedure states that actual practices and experiences do not have to consistently correspond to respondents' statements; the interview may also reflect the respondent's attitude

27 Roman MíČKA, Sociální učení církve a evropská integrace, Studia Theologica 3/2011, pp. 152-172.

28 Jakub DOLEŽEL, Spirituální citlivost charitních služeb: Proč a jak pracovat se spirituální dimenzí životní situace klientů, Caritas et veritas 7/2017, p. 35.

29 The research data was elaborated (in detail) in the bachelor thesis of the co-author of this study, cf. Alena VYSKOČILOVÁ, Možnosti křestanského společenství v podpoře inkluzivního života na př́kladu člověka s tělesným postižením, Bakalářská práce, Olomouc: Univerzita Palackého, 2017.

30 Cf. Petr PABIAN, Jak se učí na vysokých školách: výzkumný směr přístupů k učení, Aula 1/2012, p. 51.

31 Cf. Jan ŠIŠKA and Ibrahim BANGURA, Biografický fragment ze Sierry Leone jako cesta ke zkoumání př́ícin postižení, Speciální pedagogika 2/2010, pp. 136-137.

32 Cf. Pavel DOULÍK, Jiř́ ŠKODA and Martin BÍLEK, Vybrané metody pedagogického výzkumu a jejich aplikace při zkoumání experimentálních činností v přírodovědném vzdělávání, in Martin BÍLEK (ed.), Metologické otázky výzkumu v didaktice chemie, Hradec Králové: Gaudeamus, 2009. 
towards the researcher, and the subsequent interpretation of the acquired data may be distorted by the researcher's relationship to the respondent or also by the different perspective of the two involved. ${ }^{33}$ However, Prücha points out that these are, in fact, risks associated with all forms of research inquiries. ${ }^{34}$ According to Mareš, a distortion of the analysis of testimony can be prevented to a certain extent by conducting an interview with other persons on the same issue who can specify the data obtained. Also, additional questions or changes to the perspective of a testimony in the interview itself can be used (that is, returning to key themes several times during the interview). ${ }^{35}$ The interview with the respondent Jana ${ }^{36}$ was recorded (in this case) by a classical transcription, followed by an analysis of the interview with a focus on the individual periods of the life of Jana. The main topics that emerged in the interview were then categorised into several groups (by subject and by respondent's attitude). The important point was the respondent's statement that she considered the topic to be important; some of these topics were repeatedly returned to in the interview. The decoding and categorisation of testimonies revealed how to gain experience and create concepts that are decisive for the respondent's actions and which are reflected in her interaction with the environment and with society. The outputs thus obtained are interpreted in the sense of expectation of concrete forms of support by the Christian community, and we can ultimately define the possibilities of this community in promoting Jana's inclusive life.

The interview with two other respondents, Klára and Milan, was dealt with by selective transcription; the selection criteria were determined on the basis of an analysis of the interview with Jana. The basic criterion was the content match of the respondents' testimonies and four identified topics from the interview with Jana, which needed additional information from other people. We have used here the testimonies of those who are helping or directly present during help. With regard to the research intentions, the themes that were fundamental to the discovery of the possibilities (potential) and also the limitations in the promotion of the inclusion (of the individual with disabilities in the Christian community) were studied. The particularly identified and defined topics of the content criteria of selective transcription were the concept of self-help, motivation to help, the moral basis of this activity, and the reaction of the environment to a helpful approach to the disadvantaged person. During the transcription, only those parts of the testimony of both respondents (Klára and Milan) were recorded that related to these topics; other topics or repetitive parts of the testimony were omitted during transcription.

\subsection{Analysis of the Interview with Jana}

Jana herself named the fundamental problems of her life 'my greatest fears'. From her testimony, the following areas of problems emerged.

33 Cf. Jiří MAREŠ, Styly učení žákư a studentů, Praha: Portál, 1998, pp. 87-89.

34 Cf. PRŮCHA, WALTEROVÁ and MAREŠ, Pedagogický slovník..., p. 76.

35 Cf. MAREŠ, Styly učení žáků a studentů..., p. 90.

36 The identification data of all respondents are intentionally altered for study purposes; the respondent Jana was born with a form of childhood cerebral palsy without mental disability, left-handed hemiparesis, with a weakened left hand and left leg; Jana uses a care service - outpatient social service, where the basic services provided include assistance in coping with normal personal care, assistance with personal hygiene or providing conditions for personal hygiene, provision of food or assistance with obtaining food, help with the household, mediation of contact with the social environment (see Czech law Act no. 106/2006 Coll.). 


\section{Fear of the Future}

Jana repeatedly uses the word 'addicted' in her testimony - she is aware of her dependence on people in her environment in the day-to-day management of basic self-care. About this she says (for example): 'In the fifth grade, I realised I would not be able to stay home. ... For example, in the bathroom - my sister was already able to have her bath alone unlike for me, since my childhood, someone has helped me into the bath. Even when one thinks about basic things, one realises he or she needs someone else.' However, the problem of dependency on the help of others has another dimension for her. Jana responds very sensitively to the situations she perceives and refers to as 'abuse of power by the environment' (especially by authorities or institutions). In this way, she assesses, for example, her dependence on the health insurance company's decision to pay for her health care ('once my financial support will not be enough and THEY will decide ...') or the decision of the insurance company to terminate her rehabilitation for such a reason as: 'there is no expectation that the health condition will improve'. During her life she has had such and similar experiences.

\section{Distrust from the Neighbourhood}

As a form of arrogance (when one talks about power), Jana assesses the need to prove that her state of health is actually in accordance with her statement - which has been repeatedly required in medical facilities. After brain surgery, for example, she could not move her legs fully. She says about that: 'It was the most difficult thing for me to prove to the doctors that I really could not.' Similarly, she also sees the duty to prove her state of health when requesting an orthopaedic wheelchair: 'Proving that I cannot really do it took three quarters of a year. I spent that time riding around on a rented wheelchair... I personally dislike most the fact that they do not trust me...' Similar situations have had to be resolved many times in the past (which has been very humiliating from her point of view).

\section{Desire for Independence}

In her testimony, Jana describes some positive milestones in her life, such as gaining her own home (independence in living) and also becoming familiar with Christianity. She highly appreciates those achieved goals (independent living and the ability to decide about her own issues) and understands them as an opportunity to take responsibility for her own life: 'Even though some things are wrong here, it's still better than the second floor above the stairs... When I moved in here, my biggest concern (i.e., that I'll end up in some institute) was gone. Now I know that till I have another solution, it will not happen.... The experience of Christian faith then began to relieve her of many other (otherwise unsolvable) fears.

\section{Faith and Life Anchoring}

This change of life is perceived by Jana primarily as opening up entirely new possibilities. She describes how the experience of Christian faith brings her inner peace: 'I think I am not afraid of what is going to come like I was afraid before'; 'I'm not concerned about what's going to happen ... I'm not concerned about LATER now. She also reflects positive changes in her own behaviour and the improvement in her approach towards communication. Jana describes the life enrichment 
with faith in this way: 'God does for me what I have always wanted - to be useful. ... Faith also gives sense to my life. It's not just about me - what I can do and what I cannot do anymore...' We used Maslow's hierarchy of needs to decode the needs of Jana (the basis of this study is founded on the same concept of personality). ${ }^{37}$ The life story of Jana, and the development of her attitudes and motivation, corresponds exactly to Maslow's hierarchy of needs, which is used in social practice when assessing the life situation of clients, and its origins correspond to the concept of Christian social and charity work. Drapela also recommends the elements of this theory in the assisting professions when dealing with such issues as defining needs and self-actualisation, the conception of a hierarchy of needs and its implications for the client's psychological progress and motivation. ${ }^{38}$ In her testimonies, the respondent Jana describes several important experiences from different areas of life - namely, the period of her life in the institution, her family background, and the approach of her family members to her situation, but also the relationship to herself and to other people in her neighbourhood, or the experience with prejudice. Her reflection on B-values (where Jana expresses, for example, her opinion on finding a deeper sense of life through the experience of Christian faith, and also on gaining new opportunities to fulfil the need for her own usefulness) was crucial. For Jana, it is also important to share similar attitudes and values with other people - it has a very important impact on her experience with current life situation. She also recognises a number of other needs and also the fact that some of these needs cannot be fulfilled by the current social welfare system (either because of imperfect functioning or because these needs go beyond the competencies and possibilities of state-defined and guaranteed services). However, such needs can be fulfilled on the basis of informal relationships, especially in the family or in the context of a Christian (church) community (whose values, as was previously stated, are in many respects the core values of social work). In the present case, the closest and also 'helping' people (from the Christian community that Jana attends) are the respondents (and spouses) Klára and Milan.

\subsection{Analysis of the View of Helping People}

From the statements of both respondents, the areas corresponding to the defined content criteria were decoded.

\section{Concept of Help}

The first area is connected with the answer to the question of whether and how respondents themselves feel about being helpers. Klára says, 'I have always prayed to have a friend. For me, Jana is my friend, we have a nice relationship together. She always says to me: I do not need a caregiver, I need a buddy...' Milan's statement is very similar: 'I do not feel like a helper, I am happy to be among people - so I am happy we have this friend...' Both of them do not see their helping Jana as the primary element of their friendship with her, but rather as something naturally present in such a relationship.

37 This theory emphasises the psychosomatic unity and uniqueness of every person who is viewed as an integrated unit, while the existence of his or her specific needs that motivate human behavior is acknowledged. Maslow structures motivational forces into the hierarchy of needs. The highest degree of hierarchy is given to the need for self-actualisation that Maslow calls the B-level. In contrast with other authors, Maslow focuses more on philosophical, cultural, and religious themes. The difference is also in the concept of human interaction with the environment, where Maslow sees interpersonal contacts as the result of personal the result of man's personal growth and his or her self-actualisation.

38 Cf. DRAPELA, Přehled teorií osobnosti..., pp. 138-142. 


\section{Motivation to Help}

Klára usually sees Jana's needs and tries to react: 'Well, it started when I came to her. She wanted to make me tea but she was in a bad shape, so she was navigating me in order to make me useful. I had somehow spotted her needs and found out she had a sense of humour, and so I started responding to the needs with a sense of humour... Some of the muscles stop working from time to time and she ends up on the floor, so when I find her, I tell her: "Hey, why are you laying here like that?" And she laughs, because the common reactions are usually "Poor you, what happened to you?"' Thus, Klára assesses her behaviour towards Jana more like common communication and assistance which helps to find the flexible solution of certain life situations. Milan adds, 'It's not that much about a big help. Everyone has a weakness. It is just that for most people it's not a problem with hands or feet, that is, something which can be seen at first glance. For me, I was glad to get to know the new good person...' Thus, the motivation element of Klára and Milan is again a spontaneous and natural relationship, not a duty or other external factor.

\section{Moral Basis}

In his testimony, Milan sometimes went into some moral and ethical values based on his Christian lifestyle, perhaps as follows: 'We sell books, that's our job. It is interesting for me to get to know a lot of human fates. People (quite often out of nowhere) start talking to us about their lives. I had never wanted to sell books or help Jana, but when I started doing it, I found out that it was really fulfilling for me. When one is a believer, the greatest experience is an opportunity to serve others ... It makes sense to me.' His helping approach is therefore clearly based on internalised Christian attitudes and the application of certain values in everyday life, which in turn leads to spontaneous service to others.

\section{Reaction of the Environment to a Friendly Approach towards Disadvantaged People}

The last major issue concerned the reactions of other members of the community to the helpful approach of both spouses. Milan mentioned one of the specific reactions: 'Some people told me that it was a big sacrifice for us. But that kind of reaction quite surprised me...' Klára added, 'When someone talks about the sacrifice, I'm thinking more about what do they see as sacrifice?... Sometimes I notice that some people lack respect for others because they simply do not get respect from others. So I'm trying to do that in interpersonal relationships - just to respect others...' In Klára and Milan's relationship towards Jana there is definitely no use of power over the other person, nor any attempt to 'earn salvation', which, for some Christians, can easily become the motivation for good deeds. They both see their relationship with Jana as obviously equal, on each side. It is just that everyone has a different starting position.

\subsection{Needs Versus Options}

The needs of people with disabilities are, in fact, not that special. On the other hand, when they have to face their common needs, some sort of specific obstacles (quite different from those for people without disabilities) are raised..$^{39}$ Determinants that affect the lives of people with disabilities are divided by Novosad into subjective factors (so-called personality-life characteristics) and

39 Cf. Libor NOVOSAD, Poradenství pro osoby se zdravotním a sociálním znevýhodněním, Praha: Portál, 2009, pp. 27-28. 
objective factors. The first group can include, for example, the state of health and the limitations resulting from it, as well as the personality characteristics of a person which are congenital or influenced by the family, school, community, culture, and society. But it also includes self-esteem, self-realisation, or the ability to cope with unfavourable life situations. Objective factors include, for example, the policy, the values recognised by society (including access to inclusion), the environment, or the system of social services..$^{40}$ The possibilities and potential of the Christian community in the field of inclusive support for people with disabilities can then be seen through these determinants.

\section{Physiological Needs and the Need for Safety}

If we again use Maslow's theory of needs, it can be said that the family and the state share the fulfilment of the individual needs at the first two levels of the pyramid the most. The family traditionally fulfils the economic, educational, and socialisation function, and although state intervention has pushed the family's importance into new contexts during the 20th century, family relations continue to play an irreplaceable role in raising children, creating their sense of security and stability, etc. ${ }^{41}$ The role of the state is irreplaceable in the provision and availability of health care, social support, or social services.

The Church, as a Christian community, opens up a space to understand the limitations that a person has because of his or her disability. A more serious problem than the removal of physical barriers is usually personal barriers (psychological, relational, and communicative); objective information on the situation and on the everyday life of people with disabilities, as well as the willingness to find ways to reach them, can help to overcome those barriers. ${ }^{42}$ According to Jana's experience, many of those in the community are often surprised to see someone with disabilities appear (usually due to a lack of personal experience with such contact). Even within the Christian community, there are, of course, limits to the degree of willingness to mutual help, information, and personal experience, which fundamentally contribute to the elimination of barriers present on the part of people without disabilities.

\section{Social Needs}

Those needs are primarily (when a person is still a child) fulfilled by the family. From the older school-age, the role of friends - peers - is becoming more important. This allows the adolescent to emancipate him or herself from the family. ${ }^{43}$ For a person with disabilities, social services can also be a source of fulfilment of this category of needs; as Bednár points out, one of the most common shortcomings in social services is the tendency to adapt the service to external conditions rather than to the user's needs. ${ }^{44}$ The great potential in meeting sociable needs is therefore volunteering, which naturally activates the spiritual dimension of life. ${ }^{45}$ This is another great opportunity for the Christian community. In addition, the basic principles of volunteering work are fully consistent with one of the attributes of the Church, which is the application of 'caritas', that is, helping love, which traditionally happens in churches through diakonia (service to the needy) - it is even one

40 Cf. Libor NOVOSAD, Tělesné postižení jako fenomén i životní realita, Praha: Portál, 2011, p. 104.

41 Cf. Oldřich MATOUŠEK, Rodina jako instituce a vztahová sít, Praha: Sociologické nakladatelství, 1997, p. 9.

42 Cf. Josef SLOWÍK, Člověk s handicapem v křestianském společenství, Praha: Advent-Orion, 2015 , p. 63.

43 Cf. Josef LANGMEIER and Dana KREJČÍŘOVÁ, Vývojová psychologie, Praha: Grada, 1998, p. 150.

44 Cf. BEDNÁ̌̌, Kvalita v sociálních službách..., pp. 126-127.

45 Cf. SLOWÍK, Člověk s handicapem..., p. 53. 
of the four constitutive elements of the Church. ${ }^{46}$ In our story, Jana experienced both standard diakonical help from the Church and informal volunteer support from Klára and Milan.

According to Strauss, the essence of social integration (i.e., inclusion) is interdependence and human participation. ${ }^{47}$ Therefore, the Christian community has definite preconditions for fulfilling social needs - simply by the fact that it is a community (a group of people who have found a common interest and build relationships). For many Christians, therefore, the call for an inclusive approach is essentially a reflection of one's own attitude towards publicly declared Christian principles and their practical fulfilment.

\section{The Need for Respect and Recognition}

The precondition for the fulfilling of recognition - one of the human needs - is, in the case of individuals with disabilities, the openness of community members to disadvantaged individuals and finding opportunities to use their potential. This may include participation in the service on a small scale during worship or diakonia. The participation of the person concerned in the real life and functioning of the church (community) is essential. For Jana, this need is already saturated by the unconditional acceptance and friendship (not only) of the two interviewed members of the Church - the Church to which they belong, and where she does not have to prove that she is worthy of the interest and trust of others. Added value is also in the spiritual growth of not only individuals but also of the whole community - by demonstrating solidarity, the community grows to maturity and its members discover what it really means to be human. In this context there is an opportunity to learn humility, courage, and initiative in working with others. 'People can build common good only when they discover their vocation to be people of service, peace, and justice. Common good is what helps everyone to live better. ${ }^{3}{ }^{48}$

\section{The Need for Self-Actualisation}

As we have already described, the need for self-actualisation is placed (by Maslow) on the B-level, which brings B-values and the highest experiences to the life of man. ${ }^{49}$ Jana introduces her encounter with Christianity as one of her most powerful experiences. At this level of the hierarchy of needs, the possibilities of support from the Christian community actually overlap with the very essence of the mission of the Church. It is not that important nor absolutely crucial if in this area of Jana's needs predominates her own spiritual experience (respectively the personal experience of the Christian faith) or the experience of acceptance and support by the Church community - and it seems that neither of these experiences (as well as their contribution to the saturation of spiritual or social needs) can actually be reliably separated and distinguished (knowing the fact that Christian faith unrealised in the communion of Christ's body and, on the contrary, the Church without the experience of living beliefs of its individual parts, i.e., members, does not make sense). According to Vanier, many people are hiding their inner fear, and hiding from the opportunity to meet someone who trusts us despite our disabilities and can awaken our desire for liberation from hidden fears. This removes the barriers that prevent our potential from being real-

46 Cf. Michal OPATRNÝ, Služba potřebným - diakonie jako konstitutivní prvek praxe církve, In Michael MARTíNEK et al. (eds.), Praktická teologie pro sociální pracovníky, Praha: Jabok, 2008, p. 62.

47 Susanne STRAUSS, Volunteering and social inclusion, Wiesbaden: VS Verlag, 2008, p. 42.

48 Jean VANIER, Cesta k lidství, Praha: Portál, 2004, pp. 60-62.

49 Cf. DRAPELA, Přehled teorií osobnosti..., p. 139. 
ised. Love and trust awaken the best in us and lead us to spiritual growth. ${ }^{50}$ Jana's experience also corresponds to Sedláček's statement that 'happiness seems to be a by-product of doing good. ${ }^{51}$ Benedict XVI in his encyclical Deus caritas est also points out the essence of God's love, which is sacrificed on the Cross to give people hope and show the way to live in this world. He refers to the helping love called caritas and the life stories of people who in this way have reflected God's love in their lives. ${ }^{52}$ Jesus, after all, directly connects the question of salvation and help to the needy (Mt 25:35-40).

According to Boardman, the success rate of social inclusion can be measured by a number of new opportunities which the individual feels comfortable with (or is supported to use them) - professionally provided social services often fail to meet all the needs of their users without the use of volunteer work or other spontaneous help. ${ }^{53}$ Apart from the specific activities of humanitarian organisations or charity organisations, the Church as a Christian community can use the opportunities that can be realised directly in personal relationships, during worship or in informal activities (within or beyond the ecclesial community itself), where mutual support and assistance among members and friends take place.

\section{Summary and Conclusion}

The possibilities and potential of the Christian community in the field of inclusive support for people with disabilities and disadvantages is not a completely new or surprising discovery but rather a true understanding of the Church's original mission and its consistent application in interpersonal relationships while respecting the principles of human dignity and understanding of interpersonal relationships as relationships to neighbours. Virtually all definitions of inclusion emphasise individual decision-making, mutual understanding, and acceptance within the community, and wider society, as well as the creation of possibilities and opportunities to develop the potential of every person, including those with disabilities. The real possibilities of supporting people with disabilities are therefore mainly included in finding and creating opportunities, while taking into account the different constraints caused by the disability of the particular individual and the social consequences associated with these personal limits.

The specific opportunities of churches as Christian communities to promote inclusive and quality lives for people with disabilities can be found in particular in three areas. The first is the establishment of assisting organisations that guarantee the professional competence of their employees and at the same time a high standard of quality of services (of assistance or care) provided to clients. The second option is volunteering: this is a relatively new phenomenon in Czech society, and its great contribution is, among other things, the application of the element of spontaneity and the personal relationship of friendship to the other person in the sense of the term caritas, that is, as an expression of love for one's neighbour. The third option includes the possibilities of each individual member to act in everyday life in his or her personal relationships with others based on inclusive values and attitudes. To do this, we must first reflect upon our own understanding of the essence and origins of Christian faith and beliefs, including looking at each person as the image of God, understanding his or her potential given by the Creator himself, and accessing

50 Cf. VANIER, Cesta k lidství..., p. 147.

51 Tomáš SEDLÁČEK, Ekonomie dobra a zla: Ekonomie dobra a zla: po stopách lidského tázání od Gilgameše po finanční krizi, Praha: 65. pole, 2012, p. 235.

52 Cf. BENEDIKT XVI., Deus caritas est, Praha: Paulínky, 2006, pp. 55-58.

53 Cf. BOARDMAN, Social inclusion..., p. 233. 
others as neighbours in the spirit of the biblical parable of the merciful Samaritan (Luke 10:2537). However, openness to others always makes us vulnerable. It is sometimes a problem in some Christian communities that they close themselves up in order to protect their proven assurances. But the key to overcoming such fears should be the certainty of basic Christian values and the willingness to take the risk of testing the strength of one's faith and anchoring. As Vanier remarks, 'Opening up to others brings up not only the awareness of one's own fear, darkness and distrust, but also the presence of light, love and energy that will instil us in the desire to open peacefully to life and to others. ${ }^{54}$

The basic prerequisite for a pro-active approach is, among other things, good information: for example, the information about disability and its possible manifestations and implications on the physical, mental, and social levels make it possible to understand the situation of the person concerned and gain the necessary competencies for an adequate approach to him or her. Personal experiences of contact with disabled and disadvantaged people will allow us to set realistic perceptions of barriers and look for ways to overcome them, as well as opportunities to exploit the potential of each individual. The very atmosphere of accepting and creating positive attitudes and relationships among people is one of the important factors that generally support the formation of an inclusive community.

An indispensable area in which inclusive Church practice can manifest itself is also the missionary task in the sense of proclaiming the Gospel (let us not forget that this task has a universal, socially supranational character - the gospel is to be heard by all: the rich and powerful and the socially weak, and those ill, physically or otherwise affected - see Mt 28:18-20). It refers to the fulfilment of the human need of self-actualisation, that is, the search for the meaning of being (in Maslow's hierarchy again, these are the abovementioned B-needs and their sharing). In this sphere, man touches on what goes beyond him or her, and experiences a paradox when he or she realises the fact that it is not in the search for his or her own happiness, but in service to others that he or she finds individual fulfilment and true satisfaction of his or her needs. This is, at the same time, a benefit for the whole community, which then grows spiritually and strengthens its overall potential. That is why those who cannot repay the gift, help, or service should be at the centre of the attention of Christ's followers (Luke 14:12-14) - in the weakness of such people one can see the power of God the most. Such power is the source of real life for the Church (2 Cor 12:9). ${ }^{55}$

The above given conclusions can be used to a certain extent also in the field of professional social work. Matoušek, for example, points out that social service always intervenes in the client's world and it is the responsibility of the social worker to contribute to the fulfilment of client needs and the extension of his or her possibilities, so that the service is effective. The role of the social worker should therefore be adequate to the client's needs and the worker should have a certain insight into the client's life. ${ }^{56}$ The options that open up to a social worker while he or she is coming to a deeper insight into a person's (client's) situation in the context of his or her micro, mezzo, and macro dimensions then enable effective social intervention settings based on the actual needs of the individual, as well as ongoing evaluation and optimisation of service settings. However, this presupposes a basic inductive approach that does not allow stereotyping or generalisation

54 VANIER, Cesta k lidství..., p. 146.

55 Christina POWELL, Meeting the Needs of People with Disabilities Within the Church, Enrichment Journal 4/2009, () (online) available at: http://enrichmentjournal.ag.org/200904/200904_124_disabilities.cfm. Cited on 1st Feb 2018.

56 Cf. Oldřich MATOUŠEK, Klientův přirozený svět jako východisko sociální praxe, in Oldřich MATOUŠEK et al. (eds.), Sociální práce v praxi, Praha: Portál, 2005, pp. 25-26. 
towards any group of people with a selected common feature (for example, with disabilities). The search for contexts amongst a client's individual life circumstances enables the usage of the resources that are naturally available to him or her in his life - and if one of these sources can be (for a particular person) a Christian community, then it can be assumed that this resource can have great potential and has something to offer.

\section{Contact}

\section{Alena Vyskočilová BA}

kemina@email.cz

\section{Dr. Josef Slowík}

University of West Bohemia in Pilsen

Faculty of Education, Department of Pedagogy

Chodské náměstí 1, 30614 Plzeň

slowik@kpg.zcu.cz 